\title{
The Combination of Piper Caninum Blume Leaf Extract and Compost Fertilizer for Pressing Blast Disease and Improving Growth of Bali Red Rice (Oryza Sativa Linn)
}

\author{
Ni Luh Suriani ${ }^{\# 1}$, Anak.Agung Ketut Darmadi ${ }^{\# 2}$, Ni Made Susun Parwanayoni ${ }^{\# 3}$, Mohamad Hasnul Naim \\ Abd Hamid* and Bohari M Yamin ${ }^{+}$ \\ ${ }^{\# B i o l o g y ~ D e p a r t m e n t, ~ U d a y a n a ~ U n i v e r s i t y, ~ B u k i t ~ J i m b a r a n ~ C a m p u s, ~ B a d u n g, ~ 80361, ~ I n d o n e s i a ~}$ \\ E-mail: ${ }^{1}$ niluhsurianisuriani@yahoo.com; ${ }^{2}$ darmadi@udud.ac.id; ${ }^{3}$ parwanayoni@unud.ac.id
}

${ }^{*}$ Research and Instrumentation center, Universiti Kebangsaan Malaysia, Bangi, 43600 Selangor. Malaysia

${ }^{+}$Faculty of Science and Technology,Universiti Sains Islam Malaysia, Nilai 71800, Negeri Sembilan, Malaysia. Email: boharimy@gmail.com

\begin{abstract}
Blast disease is a spotting disease on the leaves that attacks rice, rice grains become empty and finally causing a significant loss in rice production. Many factors that cause blast disease include the continuous use of synthetic fertilizers and pesticides which could decrease soil fertility resulting in a decrease in rice yield. One way to restore soil fertility and increase rice production is to use organic methods such as using biopesticides and compost. The purpose of this study is to obtain the most appropriate formulation between biopesticides, P. caninum BL. leaf extract and compost to suppress blast disease and improve results in red Bali rice cultivation. This research was conducted in the field in Senganan Village, Penebel, Tabanan Bali, a flat area of about 300m above sea level. The experiment was carried out using a randomized block design (RBD) with 4 set of different treatments. The mixture of $40 \%$ compost and $2 \%$ piper caninum Bl. leaf extract was found to be the most effective formulation to suppress blast disease by $57.17 \%$ when tested in a 0.2 -hectare paddy field. The significant reduction of blast disease and the use of organic fertilizer have improved the growth of red rice as shown by the average number of tillers (12.9) and leaves $(60.5$ strands) after 12 weeks of transplant. The yield of the rice after 3 months of cultivation was 5.51 ton / ha, an increase by $2.40 \%$. The morphology of the ripen grain of $F 4$ treated clamps were studied and EDX analysis showed only carbon and oxygen are the major elements and trace amount of potassium and magnesium were detected. The crystalline nature of the rice is shown by the presence of polyhedral shape of starch with the size between 3 and $6 \mu \mathrm{m}$ in the endosperm area. The silicon was only observed in the hull layer. At an optimal extract concentration, the yield was increased significantly by $77 \%$. However, above the optimal concentration of the extract toxic behaviour was observed in both the growth and reduction of yield. This may be due to the toxicity nature of the many active components that were present in the extract. Therefore, further study is necessary to understand the mode of action and side effects that enable to assist in the modelling work for cultivation management and practices.
\end{abstract}

Keywords - Bali red rice; organic; compost; extract; P.caninum; morphology; blast.

\section{INTRODUCTION}

Blast disease caused by $P$. oryzae fungus [1] on rice cultivation is not new. However, the fact that it can infect rice plants in various stages of growth and could cause between 30 and $50 \%$ loss of production in endemic areas is a serious matter [2]. Although proper NPK fertilization can reduce the attack of blight-causing fungi the control of the disease is not always easy. High concentration of nitrogen would also increase the chance for the attack. Therefore an effort to overcome the disease on rice has been the subject of research for quite some times. Rice blast forecasting model has also been studied for application by the farmers in their planning stage [3], [4]. The use of synthetic fungicides although effective [5], [6], for longer period of time and inappropriate way of application can cause a negative impact on the rice crop ecosystem. Planting resistant rice varieties in alternating manner to confuse the fungi has been fairly successful [7]-[10]. The use of antagonistic microbes such as Enterobacter agglomerans, Seratia liguefaciens and Xanthomonas lumenescens has shown an improvement between 22 and $52 \%$ [11]. On the other hand Trichoderma harzianum was found to show higher inhibition of $71-88 \%$ growth of mycelia and spores from $P$. oryzae fungi [12], [13]. In another study at Banyuasin district, a compost 
extract was found to increase rice yields and suppressed $60 \%$ blast disease [14]. In vivo study in our laboratory using leaf extract of $P$. Cinanum also showed high inhibitory activity of $83.3 \%$ against blast disease at $2.5 \%$ concentration [15]. $P$. Cinanum is known to contain biologically active compounds against microbes including bacteria and fungi [16]. Based on this study we decided to test the effectiveness of the extract in combination with organic compost fertilizer in the cultivation field with an idea of dual functions to control the blast disease and supporting the growth of the plant as well. The optimal formulation will be useful for wider applications as bio-pesticide.

\section{MATERIALS AND METHODS}

\section{A. Experimental cultivation design}

Experimental cultivation of rice was carried out in the field at Tabanan West Bali area (longitude 115.0; latitude 8.45 and elevation $249 \mathrm{~m}$ above sea level) based on Group Random Design with 2 factors, 5 treatments and 4 replications. Altogether there are 20 experimental units and each unit consists of 5 clumps with the size of $30 \times 30 \mathrm{~cm}$. Each clump will take only 2 seeds. The size of each unit is $150 \times 150 \mathrm{~cm}$. The average annual temperature is $25.9^{\circ} \mathrm{C}$ and annual rainfall of $2178 \mathrm{~mm}$. The cultivation experiment was conducted in March till July 2018. Each clump in the unit is labelled as F0 for control; F1 = treatment with $(10 \%$ compost + extract $0.5 \%$ mixture $) ; \mathrm{F} 2=$ treatment with $(20 \%$ compost $+1 \%$ extract mixture $) ; \mathrm{F} 3=$ treatment $(30 \%$ compost + extract $1.5 \%$ mixture) and $\mathrm{F} 4=$ treatment with ( $40 \%$ compost $+2 \%$ extract mixture). The nature of the soil was sandy loam. Standard cultivation steps involving seed seeding, planting media preparation, seed planting, plant maintenance and inoculation of pathogenic fungi (P. orate).

\section{B. Scanning Electron Microscopy}

The grain rice was cut longitudinally or transversally and mounted on a circular aluminium stub and platinum-coated in a vacuum using a sputter coater. The rice morphology was examined by using scanning electron microscope energydispersive X-ray spectrometry FE-SEM, ZEISS Merlin operating at $0.2-30 \mathrm{kV}$ beam current up to $400 \mathrm{nA}$ and the lowest vacuum of few pA-300nA. In the present study $3 \mathrm{kV}$ accelerating electron was applied for the imaging and $15 \mathrm{kV}$ for EDX experiment except at the husk where $10 \mathrm{keV}$ was sufficient.

\section{Extraction of P.caninum Blume}

Forest chili leaves ( $P$. caninum Blume) were collected from plants grown in the Village of Senganan, Penebel District, Tabanan Regency, Bali. The first three matured leaves from branch end were collected because the $4^{\text {th }}$ leaf and beyond contained less active components and therefore become less active. The collected leaves were washed with clean water to remove contaminants, then cut to small pieces and wind dried for 3 days in the shade. The materials $(1 \mathrm{~kg})$ were then macerated in methanol at a ratio of 1:10 (weight / volume) for 48 hours in the dark, at room temperature. The filtrate was obtained by filtering, using 4 layers of gauze followed by filtration using Whatman filter paper No. 1 . The maceration process was repeated 3 times with methanol. The filtrate obtained were combined and then evaporated using a rotary evaporator at $40^{\circ} \mathrm{C}$ to remove the solvent (methanol). $10 \mathrm{~g}$ crude gel-like product was obtained.

\section{Organic compost Fertilizer}

The fertilizer was prepared by mixing appropriate amount of cow dung, manure chicken, rice straw and trichoderma bio-starter either isolated from local soil or as supplied by government agency and aspergillus niger in a container. Then small amount of water was added to make the total weight about $200 \mathrm{~kg}$. The container was closed for 20 days. The container was opened to release the gas and the whole mixture was thoroughly stirred. The container was closed again for 40 days after which it is ready for use [17].

\section{E. Preparation of organic pesticide-fertilizer mixtures}

Four different ratios of fertilizer-extract mixtures were prepared in $100 \mathrm{~mL}$ each. The first mixture for the first clamps is labelled as $\mathrm{F} 1$ has $10 \%$ compost and $0.5 \%$ extract. $10 \mathrm{~g}$ compost and $0.5 \mathrm{~g}$ extract were weighed and mixed in $200 \mathrm{~mL}$ container. $100 \mathrm{~mL}$ of water was added to the mixture and the mixture was stirred thoroughly. Similar procedure was repeated for the $2^{\text {nd }}$ clamp F2 (20g compost, $1 \mathrm{~g}$ extract), $3^{\text {rd }}$ clamp F3 (30g compost, 1.5 extract) and $4^{\text {th }}$ clamp F4 (40g compost, $2 \mathrm{~g}$ extract).

\section{F. Application of Pesticide-Fertilizer Mixtures}

The 20 days old germinated seed was transplanted into the clamps or unit plots. The water level was kept about $2 \mathrm{~cm}$ above soil level. After transplanting of seeds into the clamps of the unit plots the young germinated seed (about $15 \mathrm{~cm}$ height) were allowed to grow by maintaining the water flow through the well-known world heritage Subak system. The blast microbe pyricularia oryzae solution (20mL) was sprayed over the growing rice after 29 days of transplant. One day after, $20 \mathrm{~mL}$ mixed fertilizer- $P$. cinanum extract was sprayed on each clamp according to their respective treatment formulation (F1-F4). The same fertilizer-extract solution treatments were given to the growing paddy every 30 days until the fourth month. In total 4 treatments of fertilizer-extract solution were applied to the plants until harvesting stage.

\section{G. Parameters observed}

Observed and measured parameters include blast disease intensity and growth parameters (plant height, number of leaves and number of tillers). The intensity of blast disease was calculated by the following formula.

$$
I P=\frac{\sum_{i=0}^{i}(\text { nivi })}{N V} x 100
$$

Where, IP=blast intensity, ni= number of leaves with a score to $\mathrm{i}$, vi = Value of each category of disease scores, $\mathrm{N}=$ number of leaves observed, $\mathrm{V}=$ highest score.

Score for each category:

$0=$ no attack at all

$1=$ very mild attack ( $0-10 \%$ broken leaf surface $)$

$2=$ mild attack $(10-30 \%$ broken leaf surface $)$

$3=$ moderate attack (30-50\% of the leaf surface is damaged) 
$4=$ severe attack (50 - 75\% of the leaf surface is damaged)

$5=$ very heavy attack $(75-100 \%$ of the leaf surface is damaged)

The inhibitory activity was obtained by dividing the difference between the number of blast of treated clamp and the control F0 by the number of blast of F0 treated clamp and multiply by 100 .

\section{H. Data Analysis}

The data obtained were analyzed quantitatively using analysis of variance one way ANOVA $(p<0.05)$ and expressed as mean values. Statistical package SSPS Version H.O was used. If the treatment causes a difference to the observed variables, then Duncan's Multiple Range Test (DMRT) at the 5\% level was used.

\section{RESULTS AND DISCUSSION}

\section{A. Intensity of Blast disease}

The field observation clearly showed that the control clumps were very much affected by the blast diseases (Fig.1).

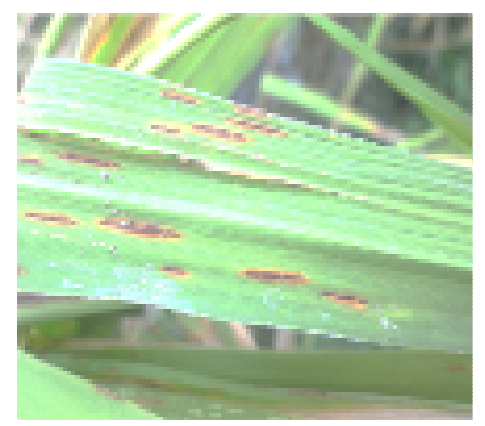

Fig. 1. The effect of blast on the leaves in the control clumps (Fo)

However, significant improvement or reduction of blast intensity was displayed by the fourth clumps F4 (Fig. 2). Table 1 shows the intensity of blast disease and inhibiting activity after 9 weeks of transplanting. At this time the green paddy started to appear. The highest intensity was displayed by control unit (F0). The decrease of intensity as the percentage of fertilizer-extract increases indicates the positive effect of the dual fertilizer-pesticide. The lowest intensity (9\%) with the highest inhibition activity (57.2\%) was displayed by formulation F4. It is a very significant cure if not all.

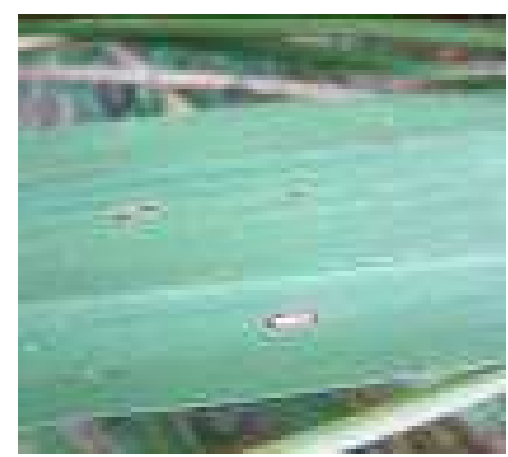

Fig. 2. Less number of blast in the F4 treated clumps
TABLE I

INTENSITY OF BLAST DISEASE AND INHIBITING ACTIVITY AFTER 9 WEEKS OF TRANSPLANT

\begin{tabular}{|l|l|l|l|}
\hline No & Treatment & $\begin{array}{l}\text { Intensity of blast } \\
\text { disease }(\%)\end{array}$ & $\begin{array}{l}\text { Inhibiton } \\
\text { activityy }(\%)\end{array}$ \\
\hline 1 & Fo & $66.18 \pm 0.01$ & - \\
\hline 2 & F1 & $44.20 \pm 0.00$ & 33.2 \\
\hline 3 & F2 & $24.20 \pm 0.05$ & 63.6 \\
\hline 4 & F3 & $10.30 \pm 0.03$ & 84.4 \\
\hline 5 & F4 & $9.01 \pm 0.01$ & 86.4 \\
\hline
\end{tabular}

The trend of change of both blast intensity and inhibition activity against the concentration of the extract is apparently linear at the beginning looked closer to exponential within the standard error towards the end as shown in Fig. 3.

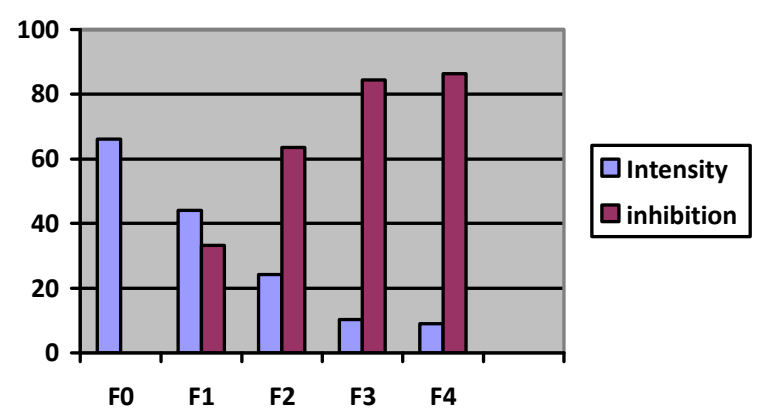

Fig. 3 The relationship of intensity of blast disease and inhibitory activity with the increasing fertilizer-extract concentration

The effectiveness of the treatment is displayed by further decrease of intensity of blast disease after 15 weeks, close to the harvesting stage (Table 2).

TABLE II

INTENSITY OF BLAST DISEASE AND INHIBITION ACTIVITY AFTER 15 WEEK

\begin{tabular}{|l|l|l|l|}
\hline No & Treatment & $\begin{array}{l}\text { Intensity of blast } \\
\text { disease }(\%)\end{array}$ & $\begin{array}{l}\text { Inhibition } \\
\text { activity }(\%)\end{array}$ \\
\hline 1 & Fo & $79.11 \pm 0.12$ & - \\
\hline 2 & F1 & $30.17 \pm 0.48$ & 60.1 \\
\hline 3 & F2 & $20.15 \pm 0.01$ & 74.5 \\
\hline 4 & F3 & $8.39 \pm 0.01$ & 89.4 \\
\hline 5 & F4 & $7.11 \pm 0.05$ & 91.0 \\
\hline
\end{tabular}

Limiting the dosage of P. caninum extract up to $2 \%$ in the $\mathrm{F} 4$ formulation was based on our previous in vitro antifungal activity of P. caninum Blume extract against pyricularia oryzae and later study on its efficacy when applied to red rice plot in the laboratory glasshouse environment [18]. The caninum extract showed a strong inhibitory activity with inhibition zone of $44 \mathrm{~mm}$ and MIC value of $0.5 \%(\mathrm{w} / \mathrm{v})$. In the efficacy study, $90.5 \%$ inhibition and 7.43 blast intensity were obtained at $2.5 \%$ P.cinanum extract and gave the highest grain yield of $11.43 \mathrm{t} /$ hactare but at $3.5 \%$ extract the intensity of blast disease increased to 12.93 and the yield decreased to 7.84 ton/hectare. The soil and urea fertilizer are not likely the main reasons for it.

Therefore, the plant extract at higher concentrations has become toxic to the plant. Chemical constituents in P.caninum plant has been studied quite extensively. Some 
phytochemical substances in the form of alkaloids, flavonoids, steroids and polyphenols were reported. The two amides are N-isobutyl-15-(3',4'-methylenedioxyphenyl)2E,4E-12E-pentadecatrienamide(1), N-iosobutyl(2E,4E, 14Z)-eicosatrienamide (2), and six flavonoids; 5hydroxy-7-methoxyflavone, (3), 4'-hydroxy-5,7dimethoxyflavone(4), 4',5,7-trimethoxyflavone (5), 5,7dimethoxyflavone (6), 2'-hydroxy-4'6'-dimethoxychalcone (7) and 5,7-dimethoxyflavanone (8) as shown in Figure 4 were isolated and characterized [19], [20]. The extract displayed weak antibacterial activity against selected bacteria except compound (7) against bacillus subtilis with MIC of $125 \mu \mathrm{g}$ [19]. In general gram negative bacteria are more resistant due to thicker outer membrane and greater antibacterial against gram positive bacteria.

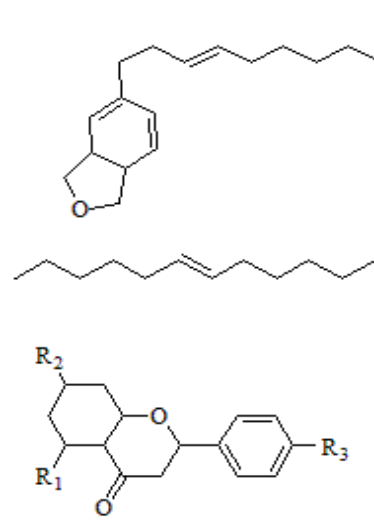

(1)

(3) $\mathrm{R}_{1}=\mathrm{OH}, \mathrm{R}_{2}=\mathrm{OMe}, \mathrm{R}_{3}=\mathrm{H}$

(4) $\mathrm{R}_{1}=\mathrm{R}_{2}=\mathrm{OMe}, \mathrm{R}_{3}=\mathrm{OH}$

(5) $\mathrm{R}_{1}=\mathrm{R}_{2}=\mathrm{R}_{3}=\mathrm{OMe}$

(6) $\mathrm{R}_{1}=\mathrm{R}_{2}=\mathrm{OMe}, \mathrm{R}_{3}=\mathrm{H}$

(2)

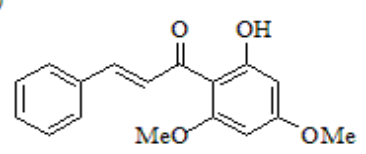

(7)

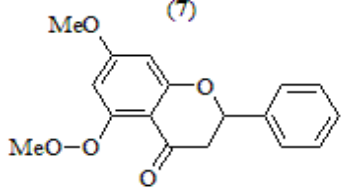

(8)

Fig. 4 Some isolated compounds from P.caninum Bl.

The essential (EO) from the stem and leaves of P.caninum was also studied by many chemists [21], [22]. The most abundant oil in the leaves are safrole, $\beta$-caryophyllene, $\beta$ pinene and germacrene and linalool whereas in the stem are phenylpropanoid, monoterpene and sesquiterpenes. They all possess strong antibacterial activity [23].

Out of 311 registered fungicides only seven are antagonistic microorganism. Out of seven antagonistic microorganisms only one is plant origin; Raynoutria sachalinensis as bio protectant internal defiance system that prevent growth of pathogenic fungi especially powdery mildew and grey mold [24]. In an update study on phytochemical and pharmacology of three piper species, Chan and Wong found that P.caninum inhibit pathogenic yeast of candida albicans Rhodotorularubra and Torulopsis glabrata but not Cayptococcus neoformans [25].

Therefore, in the use of plant with anti-fungal activity it is important to understand the mode of action and the side effects. It is known that some fungicides can cause acute toxicity and chronic toxicity as well and plant extract fungicide is no exception. Furthermore some fungi can produce toxin. Such phenomenon is manifested by the increase of blast intensity when extract of P.caninum was increased above certain threshold value in the efficacy study by Sariani [17], [18]. The use of compost containing microbe such as Enterobacter cloacae bacteria, Aspergillus niger and Trichoderma $s p$ fungi in organic farming is well established. Trichoderma sp can inhibit the development of the fungus $P$. oryzae which causes blast disease in rice. Enzymes released by the fungus Trichoderma $s p$ can lyse the cell wall of the fungus $P$. oryzae [12].

It seems that the additional effect by having the mixture of plant extract, good bacteria and fungi to combat the bad fungi and to help growth is not a simple mathematics. The mode of action is also quite complicated where the microbes are working under the presence of huge number of chemical components with toxicity and inhibitory capability. A different mode of action must have taken place at high concentration. For example, the non-polar component of essential oil can dissolve the wax layer on the leaves and allow the blast to grow easily. The side effect on the tiller, pinnacle and other parts can result in acute toxicity to the plant that will also inhibit the action of the gibberellin hormone which is important for growth and height. Intake of nutrients would also be disrupted. A detailed study to look at the effects is necessary in order to understand the overall mode of action and side effects.

\section{B. Growth}

The growth of the paddy young seed after transplanting was monitored by measuring the tillers, the number of leaves and height after the 4, 8 and 12 weeks. Table 3 shows the development of tillers over the periods. In the $4^{\text {th }}$ week all the units showed at least 10 tillers except control clamps have about 6 tillers. All the clamps possessed about 12 tillers after the $8^{\text {th }}$ week. After $12^{\text {th }}$ week the control clamps had only 8.5 tillers while the others maintain about 12 tillers. For Bali red rice, the average tillers between 8 and 13 is considered normal and genetically moderate. Again the highest tillers displayed by treatment F4 with 12.9 On the contrary, the usual hybrid rice under favorable condition could give the average number of tillers up to 38 .

TABLE III

THE EFFECT OF FERTILIZER-EXTRACT MIXTURE FORMULATION ON THE AVERAGE NUMBER OF TILLERS OF THE RICE PLANT

\begin{tabular}{|l|l|l|c|}
\hline \multirow{2}{*}{$\begin{array}{l}\text { Fertilizer- } \\
\text { extract } \\
\text { mixture }\end{array}$} & \multicolumn{3}{|c|}{ Tillers } \\
\cline { 2 - 4 } formulation & \multicolumn{3}{|c|}{ Week $(4,8,12)$} \\
\cline { 2 - 4 } & 4 & 8 & 12 \\
\hline F0 & $6.5 \pm 0.06$ & $8.5 \pm 0.33$ & $8.5 \pm 0.15$ \\
\hline F1 & $10.1 \pm 0.20$ & $12.1 \pm 0.23$ & $10.5 \pm 0.29$ \\
\hline F2 & $10.2 \pm 0.08$ & $12.5 \pm 0.23$ & $12.5 \pm 0.32$ \\
\hline F3 & $10.5 \pm 0.29$ & $12.7 \pm 0.31$ & $12.7 \pm 0.06$ \\
\hline F4 & $13.7 \pm 0.29$ & $13.1 \pm 0.13$ & $12.9 \pm 0.23$ \\
\hline
\end{tabular}

The number of leaves increases after transplanting up to the $8^{\text {th }}$ week (Table 4). The clamps treated with F3 and F4 showed the highest number of leaves after the $4^{\text {th }}$ week. After 8 weeks the clamps treated with F3 showed the highest leaves of 70.4 while the control and the clamps treated with F1 and F2 have about the same number of leaves but nearly half of the F3 treated clamp. The F4 treated clamp still showed relatively high number of leaves compared to the F1 and F2 treated clamps. All the clamps showed reduction in 
the number of leaves after the $12^{\text {th }}$ week. This is due to aging after certain time.

TABLE IV

THE EFFECT OF FERTILIZER-EXTRACT MIXTURE FORMULATION ON THE AVERAGE NUMBER OF LEAF OF THE RICE PLANT

\begin{tabular}{|c|c|c|c|}
\hline \multirow{2}{*}{$\begin{array}{l}\text { Fertilizer- } \\
\text { extract } \\
\text { mixture } \\
\text { formulation }\end{array}$} & \multicolumn{3}{|c|}{ Leaf } \\
\hline & \multicolumn{3}{|c|}{ Week $(4,8,12)$} \\
\hline F0 & $28.8 \pm 0.17$ & $45.5 \pm 0.40$ & $35.1 \pm 0.58$ \\
\hline $\mathrm{F} 1$ & $28 \pm 0.12$ & $45.7 \pm 0.06$ & $37.1 \pm 0.17$ \\
\hline F2 & $30 \pm 0.12$ & $47.5 \pm 0.23$ & $40.8 \pm 3.1$ \\
\hline F3 & $42 \pm 0.00$ & $70.4 \pm 0.12$ & $60.5 \pm 3.3$ \\
\hline $\mathrm{F} 4$ & $43 \pm 0.29$ & $65.4 \pm 0.03$ & $60.5 \pm 1.0$ \\
\hline
\end{tabular}

The first four weeks the untreated control clamps showed a slow growth relative to the treated clamps (Table 5). However, they all reached about the same height in the 8th week. After 12 weeks surprisingly the control clamps showed slightly taller than the rest. In fact the height of F4 treated clamps is slightly shorter than the others. The final height between 167 and $180 \mathrm{~cm}$ seem acceptable under the current environment although height up to $200 \mathrm{~cm}$ has been observed and at this height the tree might have bend and fell down to the ground.

TABLE V

THE EFFECT OF FERTILIZER-EXTRACT MIXTURE FORMULATION ON THE AVERAGE NUMBER OF HEIGHT OF RICE PLANT

\begin{tabular}{|l|l|l|l|}
\hline \multirow{2}{*}{$\begin{array}{l}\text { Fertilizer- } \\
\text { extract } \\
\text { mixture } \\
\text { formulation }\end{array}$} & \multicolumn{3}{|c|}{ Height $(\mathrm{cm})$} \\
\cline { 2 - 4 } & \multicolumn{3}{|c|}{ Week $(4,8,12)$} \\
\hline F0 & $28.3 \pm 0.46$ & $119.8 \pm 0.46$ & $179.7 \pm 0.38$ \\
\hline F1 & $39 \pm 0.58$ & $122.1 \pm 0.067$ & $176.6 \pm 0.08$ \\
\hline F2 & $39.2 \pm 0.12$ & $120.5 \pm 0.13$ & $175.1 \pm 0.40$ \\
\hline F3 & $40.7 \pm 0.12$ & $116.4 \pm 0.49$ & $172.4 \pm 0.72$ \\
\hline F4 & $40.5 \pm 0.97$ & $116.3 \pm 0.17$ & $167.7 \pm 1.1$ \\
\hline
\end{tabular}

\section{Crop and Yields}

Despite the disease the plants still grow and reach a reasonable height and gave grains indicating the resistance capability of the brown rice plant against the infection. The untreated clamps F0 have the longest stem $(179 \mathrm{~cm})$ but many of them have bent and felt to the ground (Fig. 5) compared to F4 treated (Fig.6) and the rest during the latter part of the ripening phase or harvesting stage. It is known that under proper cultivation condition, brown rice could reach $220 \mathrm{~cm}$ but will certainly bend and fell to the ground during the later stage of the ripening phase due to overweight of the grain.

Although F0 treated clamps had the lowest tillers, the number of grain/panicle is also the lowest but not very much different than the treated clamps (Table 6). However, the percentage of empty grain in the control clamps is the highest $(11.74 \%)$ while the F3 and F4 treated had only about $2.89 \%$. F4 treated clamps again showed the highest full grain weight/clump. So, the infected clumps without treatment certainly have low yield.

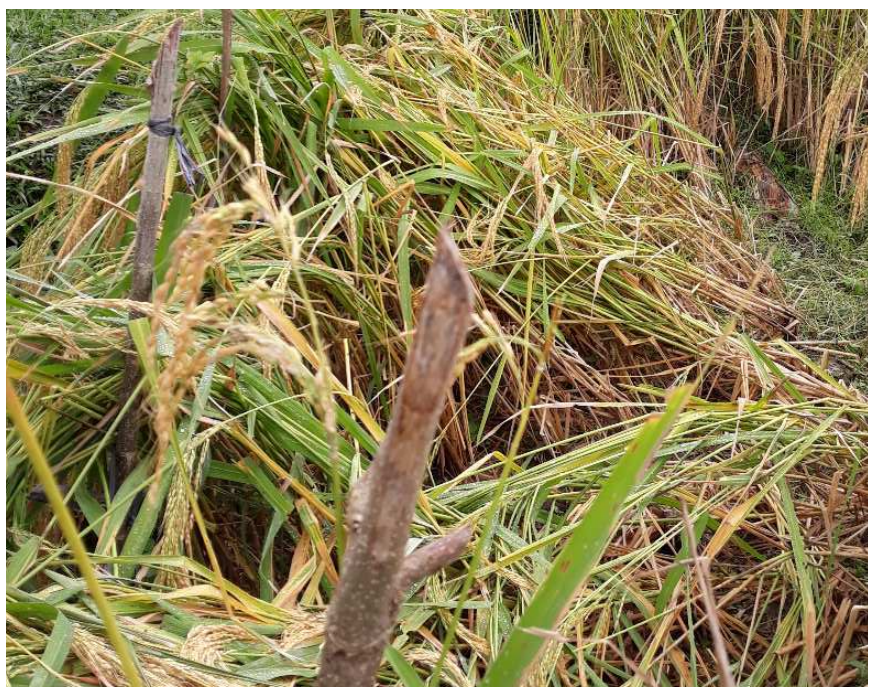

Fig. 5. Control rice plant (F0) after ripening stage 14 week after transplant

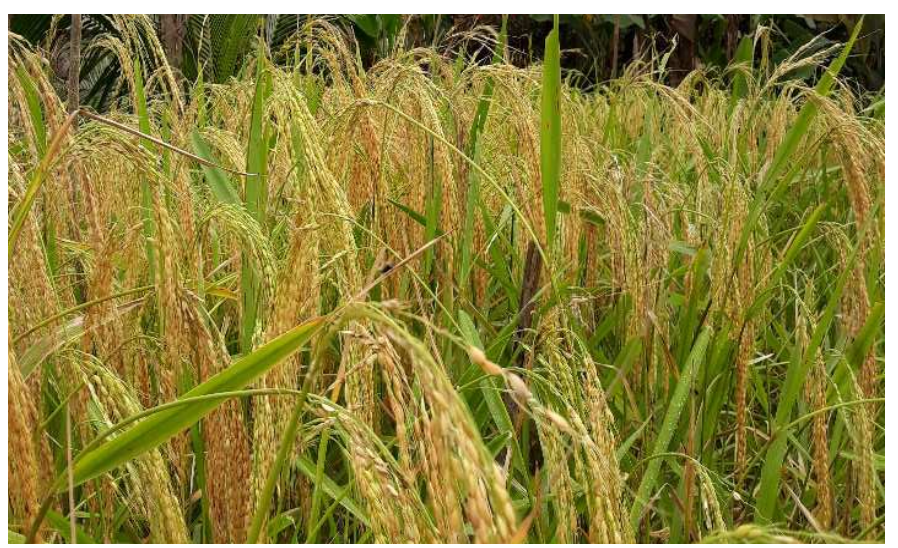

Fig. 6 F4 treated clamps during harvesting time 14 week after transplant

TABLE VI

EFFECT OF LEAF EXTRACT TREATMENT ON YIELD COMPONENTS OF RICE PLANTS

\begin{tabular}{|l|l|l|l|l|}
\hline $\begin{array}{l}\text { 蛋 } \\
\stackrel{\Xi}{\Xi}\end{array}$ & $\begin{array}{l}\text { Number } \\
\text { of } \\
\text { productive } \\
\text { tillers }\end{array}$ & $\begin{array}{l}\text { Number of } \\
\text { grain/panicle }\end{array}$ & $\begin{array}{l}\text { Full grain } \\
\text { weight/clump } \\
\text { (gram) }\end{array}$ & $\begin{array}{l}\text { Percentage } \\
\text { of empty } \\
\text { grain/clump } \\
(\%)\end{array}$ \\
\hline Fo & $8.5 \pm 0.5$ & $218.81 \pm 0.81$ & $41.60 \pm 0.23$ & $11.74 \pm 0.3$ \\
\hline F1 & $10.5 \pm 0.12$ & $234.24 \pm 0.62$ & $52.80 \pm 0.01$ & $9,59 \pm 0.27$ \\
\hline F2 & $12.5 \pm 0.29$ & $237.50 \pm 0.23$ & $60.91 \pm 0.40$ & $7.62 \pm 0.31$ \\
\hline F3 & $12.7 \pm 0.06$ & $240.76 \pm 0.19$ & $79.98 \pm 0.61$ & $2.89 \pm 0.18$ \\
\hline F4 & $12.9 \pm 0.94$ & $240.78 \pm 0.21$ & $80.23 \pm 0.07$ & $275 \pm 0.14$ \\
\hline
\end{tabular}

It is clear that F4 treatment showed positive result with the highest increase of potential yield of $77.2 \%$ (Table 7). The size distribution of the grain was quite consistent (Table 8) with an average length-width ratio of 2.38 indicating that it could be classified as medium grade rice. 
TABLE VII

POTENTIAL YIELD AND YIELD INCREASE

\begin{tabular}{|l|l|l|}
\hline Treatment & $\begin{array}{l}\text { Potential yield } \\
\text { (ton/ha) }\end{array}$ & $\begin{array}{l}\text { Yield increase compared } \\
\text { with control (\%) }\end{array}$ \\
\hline F0 & $3.11 \pm 0.24$ & - \\
\hline F1 & $3.78 \pm 0.36$ & 21.5 \\
\hline F2 & $4.22 \pm 0.06$ & 35.7 \\
\hline F3 & $5.44 \pm 0.09$ & 74.9 \\
\hline F4 & $5.51 \pm 0.05$ & 77.2 \\
\hline
\end{tabular}

TABLE VIII

Average Size of Red Bali Rice for EACH ClampS

\begin{tabular}{|c|c|c|c|}
\hline Treatment & Long $(\mathrm{mm})$ & Wide $(\mathrm{mm})$ & Diameter $(\mathrm{mm})$ \\
\hline F0 & $0.51 \pm 0.06$ & $0.20 \pm 0.01$ & $0.3 \pm 0.02$ \\
\hline F1 & $0.53 \pm 0.06$ & $0.23 \pm 0.06$ & $0.35 \pm 0.01$ \\
\hline F2 & $0.60 \pm 0.17$ & $0.25 \pm 0.06$ & $0.35 \pm 0.05$ \\
\hline F3 & $0.65 \pm 0.06$ & $0.28 \pm 0.17$ & $0.37 \pm 0.01$ \\
\hline F4 & $0.70 \pm 0.8$ & $0.31 \pm 0.06$ & $0.42 \pm 0.01$ \\
\hline
\end{tabular}

\section{Morphology of ripen rice grain by Scanning electron} microscopy

It is not easy to see all sections or parts in a ripen rice grain clearly. Special technique of sampling preparation minimizing the structural damage has been developed by Kawamoto [26] called cryomicrotome enable to see all the parts including the soft and sensitive of the area such as embryo intact but in the process s several slides and pictures are needed to look for the best one [ 27,28]. The best F4 treated clamp has the lowest empty grain per clamp (Table $6)$. Some filled grains without removing the hull were chosen and cut carefully, and the less damaged cross sections were selected for the morphology observation by using electron scanning microscopy. Fig.7 (a) shows the longitudinal cross-section of the rice grain with the upper ventral (Awn) on the left side and the dorsal part with the embryo on the right-hand side at $23 \mathrm{x}$ magnification. The outer most layer is the hull, and the upper part of the inner rice is almost separated from it with big empty-space in between. At $73 \mathrm{X}$ magnification at the upper part of the grain, we can see several layers after the hull toward inside the rice (Fig. 7b).

However, it is not easy to identify the pericarp, seed-coat, nucellus and aleurone layers. Unlike much-colored rice, the pericarp layer is easily distinguishable due to their anthocyanin color and can be removed, the color of the Bali red rice is homogenous in the whole body of the rice as shown in Figure 8. The subaleurone and inner endosperm are observed. The thickness of the hull is about 72 micron.

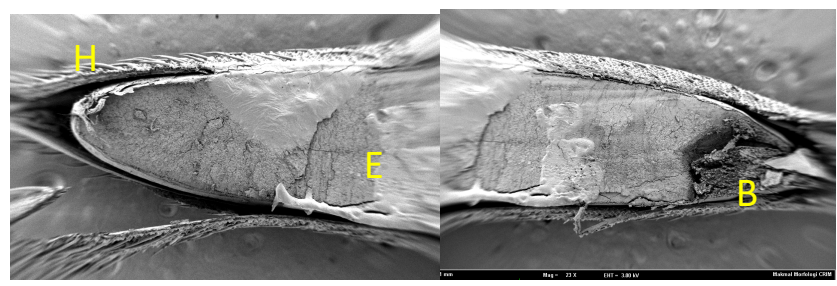

Fig. 7. (a) Longitudinal cross-section of red Bali rice at a $23 \mathrm{X}$ magnification at $3 \mathrm{keV}$. $\mathrm{E}=$ endosperm; $\mathrm{H}=$ hull; $\mathrm{B}=$ Embryo

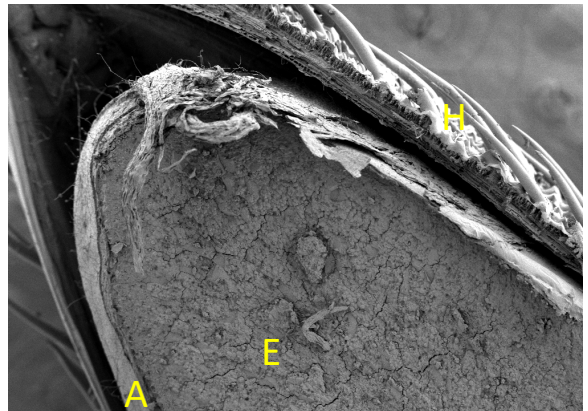

Fig. 7(b). Morphology of the upper part of the grain at 73-times magnification. $\mathrm{H}=$ hull; $\mathrm{E}=$ endosperm; $\mathrm{A}=$ Aleurone

At 500 time magnification, there are two layers probably Aleurone and subaleuron layers with a thickness of 20 and 7 microns respectively (Figure 7c).

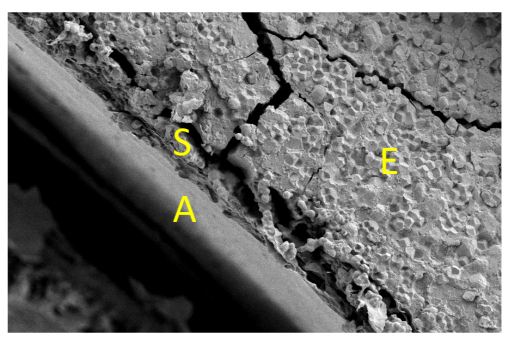

Fig. 7c. Micrograph showing the Aleurone and subaleurone layers at 500X magnification. $\mathrm{A}=$ Aleurone; $\mathrm{SA}=$ subaleurone; $\mathrm{E}=$ endosperm

In the endosperm area, the polyhedral starch crystals of size between 3 and six $\mu \mathrm{m}$ were observed (Fig. 7d). There are also few crystals with spherical shape.

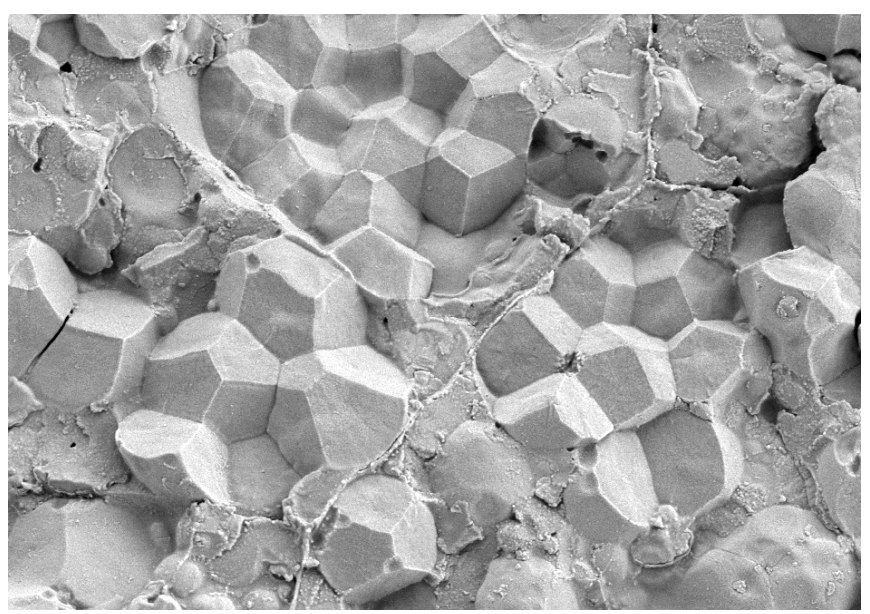

Fig. 7d. The polyhedral crystals of starch in the endosperm area at $3000 \mathrm{X}$ magnification

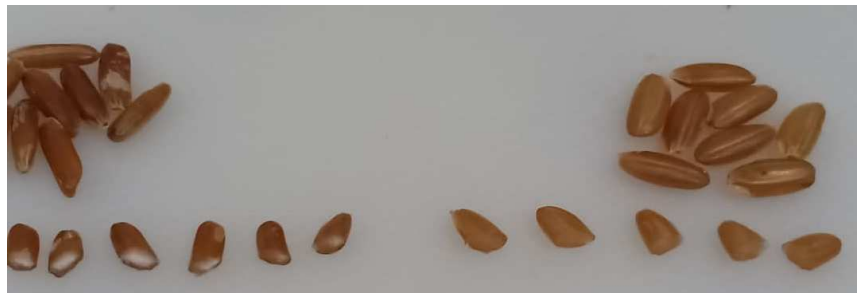

Fig. 8. Photograph of Padang (left) and Bali (right) red rice

\section{E. Transversal cross section}

In the transversal cross-section (Fig. 9a), we could see the individual aggregated polyhedral crystals as shown in the longitudinal cross-section is packed in blocks or cells of 
different sizes and linked to one another and formed like a radial chain towards the center of endosperm.

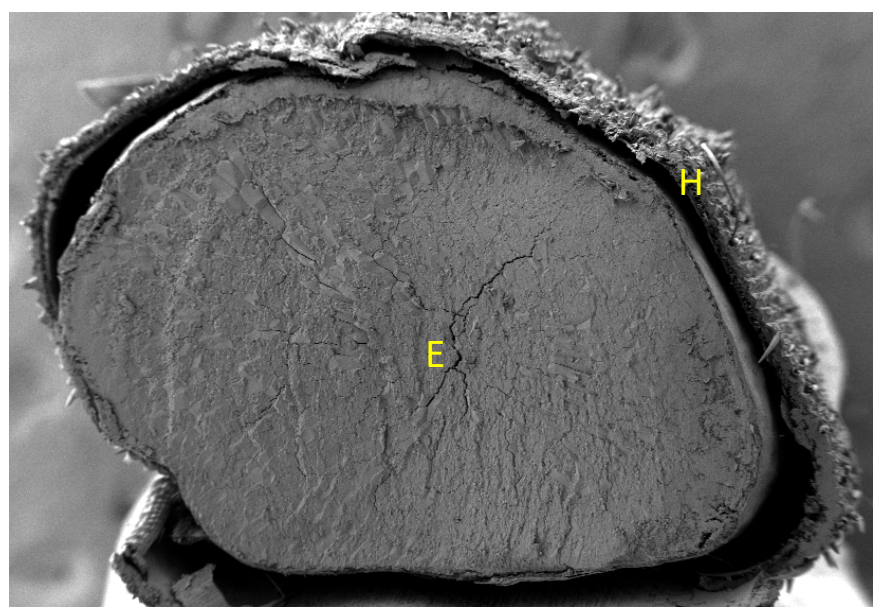

Fig. 9a. The transversal section of the Bali red rice at 39-time magnification. The outer most layer is the hull. $\mathrm{H}=$ hull; $\mathrm{E}=$ =endosperm

There also individual crystals that are closely agglomerated located either between the blocks or sporadically distributed at the center of the endosperm (Fig. $9 b)$. It is likely that the packing of crystallites occurred from the outer surface toward the center of the endosperm. The length of the block or cell is between 20 and 226 microns.

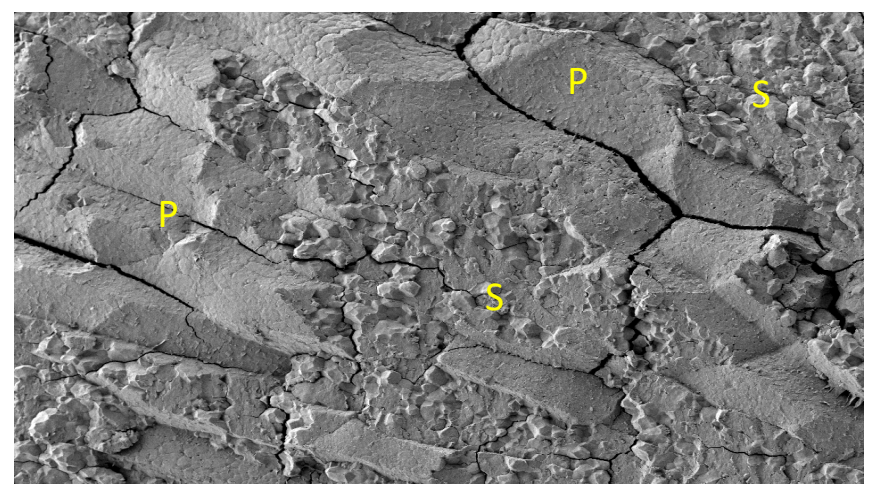

Fig. 9b. The micrograph near the central part of endosperm at 300-time magnification. $\mathrm{P}=$ block or cell; $\mathrm{S}=$ agglomerated crystals

\section{F. Elemental Determination by Energy-Dispersive X-ray (EDX) Analysis}

EDX is the easiest and quickest technique to detect elements and do semi-quantitative analysis. It may not be accurate if the presence of the elements is low below than $3 \%$ by weight. Carbon, oxygen, $\mathrm{Na}, \mathrm{Mg}, \mathrm{Si}, \mathrm{P}, \mathrm{K}, \mathrm{Ca}$ and $\mathrm{Al}$ have been detected in the hull section of the rice grain [29]. However, at $15 \mathrm{keV}$ the Bali red rice hull showed only the presence of $\mathrm{C}(60.3 \%), \mathrm{O}(26.5 \%)$ and $\mathrm{Si}(2.6 \%) \mathrm{K}$ and $\mathrm{Mg}$ were detected in the area closed to the seed coat part of the grain as trace elements with a weight percentage of 1.6 and 0.5 respectively (Figure 10). Much higher content of $\mathrm{Si}$ and other elements were detected in conventional rice by XRF and ICP, neutron activation analysis (INAA), EDXRF methods [30], [31]. No silicon was detected in the internal part of the grain. The endosperm and bran area is carbon and oxygen only.

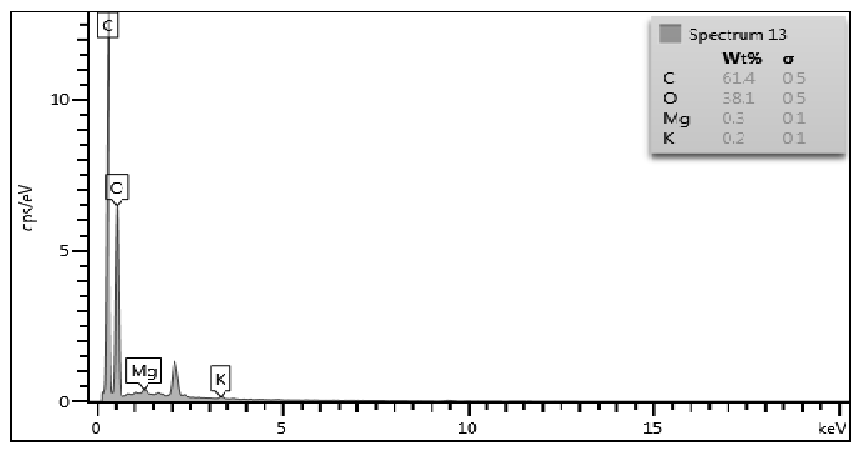

Fig. 10. EDX spectrum at the Aleuron area

The elemental mapping of the postural ventral part of rice grain (Fig. 11) shows the distribution of silicon (blue dots) only in the rice hull or husk.

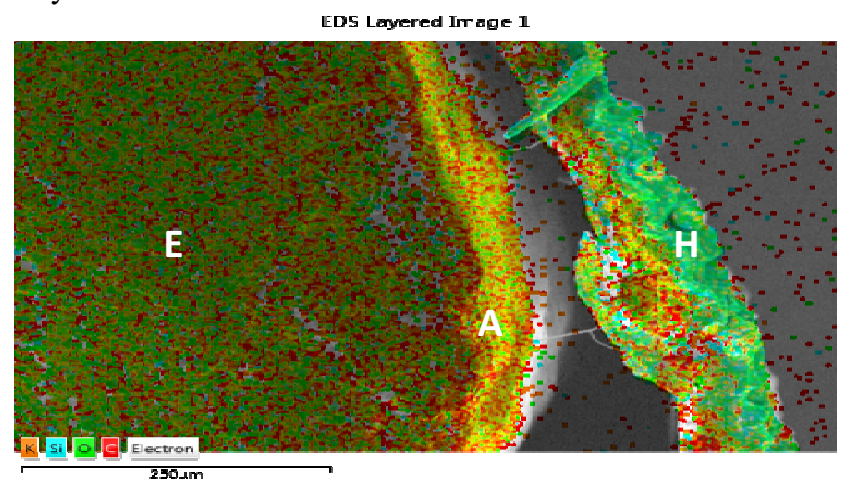

Fig. 11. Elemental mapping of the postural ventral part of the longitudinal cross section

\section{CONCLUSION}

The studies demonstrated the application of organic compost-plant extract, in particular, P.caninum to combat blast disease and to promote the growth as well in rice cultivation in the field. At optimal extract concentration, the yield was increased significantly by $77 \%$. However, above the optimal concentration toxicity behavior was observed in both the growth and yield. This may be due to the toxicity nature of the many components that were present in the extract. Therefore further study is necessary to understand the mode of action and side effects that enable to assist in the modeling work for cultivation management and practices.

\section{ACKNOWLEDGMENT}

The authors would like to thank the Research Directorate of the Ministry of Research, Technology and High Education of Indonesia for grant No. 171.121/UN14.4.A/LT/2018 and Universitas Udayana for the facilities. Special thanks to Research and Instrumentation Centre of Universiti Kebangsaan Malaysia for the morphology and elemental distribution analysis.

\section{REFERENCES}

[1] M. G. Asfaha, T.Selvarajand G.Woldeab.Assessment of disease intensity and isolates characterization of blast disease (PyriculariaoryzaeCAV.) from South West of Ethiopia. Int. J. of Life Sciences, Vol. 3(4): pp. 271-286 2015.

[2] L. Nalley, F. Tsiboe, A. Durand-Morat, A.ShewandG.Thoma, Economic and Environmental Impact of Rice Blast Pathogen (Magnaportheoryzae) Alleviation in the United States. PLoS ONE 11(12): e0167295. 2016. 
[3] D. Katsantonis, K. Kadoglidou, C. Dramalis, P. Puigdollers, Rice blast forecasting models and their practical value: a review. Phytophatalogia Mediterranea, 56, 2, pp.187-216.2017.

[4] A.R.Malicdem and P.L.Fernandez, Rice blast disease forecasting for the northern Philippines.WSEAS Transaction of Information Science and Application. Vol 12, pp.120- 1282015.

[5] A. Ghatak, L.Willocquet, S. Savary and J. Kumar, Variability in aggressiveness of rice blast (Magnoportheoryzae) isolates originating from rice leaves and neck: A case of pathogen specialization? PLoS ONE 8(6), e6618https://doi.org/10.137/1/journal pone 0066180. 2013.

[6] P. Ghimire, P.C. Gopal, S.M. Shrestha, and G. Parajuli, evaluation of fungicides and bio-agent against black neck disease of rice. J. PhatolMacrobiol, pp. 8-12. 2017.

[7] G. Miah, M.Y. Rafii, M.R. Ismail, M. Sahebi, F.S.G. Hashemi, O. Yusuff, and Usman, M.G. Blast disease intimidation towards rice cultivation: A review of pathogens and strategies to control. The Journal of Animal \& Plant Sciences, 27(4), pp1058-66.2017.

[8] G. Miah, M.Y. Rafii, M.R. Ismail, A.B. Puteh, H.A. Rahim, and M.A. Latif, Recurrent parent genome recovery analysis in a major assisted backcrossing program of rice (Oryza Sativa L.). C.R. Biol 338(2), pp. 63-94. 2015.

[9] G.Miah, M.Y. Rafii, M.R. Ismail, A.B. Puteh, H.A. Rahim, S. Askhani, and M.A. Latif, Inheritance pattern and identification of microsatellite markers linked to the rice blast resistance in $\mathrm{BC} 2 \mathrm{~F} 1$ population of rice breeding. Bragantia, 74(1), pp. 33-41. 2015.

[10] X. Wang M.Jia, P. Ghai, F. Lee, and Y.Jia. Genome-wide association of rice blast disease resistance and yield-related components of rice. Molecular Plant-Microbe Interactions. 28: pp. 1383-92. 2015.

[11] W-F. Law, H.L. Hooi-LengSer, T.M. Khan, L-H. Chuah, P. Pusparajah, K-G. Chan, B-H. Goh, and L-H. Lee,.The Potential of Streptomyces as Biocontrol Agents against the Rice Blast Fungus, Magnaportheoryzae (Pyriculariaoryzae), Front. Microbiol. 8:3. DOI: $10.3389 /$ fmicb.2017.00003. 2017

[12] D.N. Suprapta, Potential of Microbial Antagonists as Biocontrol Agents against Plant Fungal Pathogens. J. ISSAAS18 (2), pp.1-8. 2012.

[13] S. Gomathinayagam, M. Rekha, S. SakthivelMurugan and R.C. Jagessar.Biological control of rice disease (blast) by using trichodermaviride in laboratory conditions. Proceedings of the Caribbean Food Crops Society. 45: pp. 138-140. 2009

[14] S. Kumar, A. A Lal, N. Kumar, S.Jaiswal, H. Kumar, A. Kumar, and M Kumar, Effect of biocontrol agents and botanicals against Blast of Paddy caused by Pyriculariaoryzae International Journal of Chemical Studies, 5(1), pp. 314-318. 2017.

[15] L. Suriani, Bioactive Substance Use of Leaf Extract of Piper caninumBlume Pressing for Blast Disease and Increase Production in Rice. International Journal IJLS 2(2): pp. 42-50. 2018.

[16] N.L. Suriani, D.N.Suprapta, I.M. Sudana.I. M and R. M. Temaja, Antifungal activity of Piper caninum against Pyriculariaoryzae Cav. The cause of rice blast disease on rice. International journal ISTE. 5(8):72-78. 2015
[17] N.L. Suriani, N. M. S. Parwanayoni, I.W. Sudatri, and N. M Suartini,.Meningkatkan Produksi Bunga Potong Anthurium dengan Memanfaatkan Pupuk Organik. Jurnal Udayana Mengabdi 15(2), pp.19-23. 2015.

[18] N.L. Suriani, Bioactive Substance Use of Leaf Extract of Piper caninumBlume Pressing for Blast Disease and Increase Production in Rice. International journal IJLS 2(2): 42-50. 2018

[19] W.M.N.H.W. Salleh, F. Ahmad, and K.H. Yen, Chemical constituents from Piper caninum and antibacterial activity. Journal of Applied Pharmaceutical Science, vol 5(06), pp. 020-025. 2015.

[20] N.L.Suriani, Identification of the Substance Bioactive Leaf Extract Piper caninumPotential as Botanical Pesticides. International Journal IJPAB. 4 (4), pp.26-32. 2016

[21] Salleh, W.M.N.H.W., Ahmad, F., Yen, K.H and Sirat, H.M. Chemical composition, antioxidant and antimicrobial activities of essential oils of Piper caninum Blume. Int..J.Mol. Science. 12, pp. 7720-31. 2011.

[22] S.Chouhan, K. Sharma and S.Guleria, Antimicrobial Activity of Some Essential Oils-Present Status and Future Perspectives, Medicines 4, 58; DOI: 10.3390/medicines4030058, pp. 1-20. 2017.

[23] R. Randrianariveloa, S. Sarterb, E. Odouxc, P. Bratc, M.Lebrunc, B.Romestandd, C.Menute, H.S.Andrianoelisoaf, M.Raherimandimbyg and P.Danthuh, Composition and antimicrobial activity of essential oils of cinnanosmafragrans, Food Chems, 114, pp. 680-684. 2009.

[24] D.N. Suprata, Review of tropical plants with antifungal activities against plant fungal pathogen. www.preprints.org, DOI: 10.20944/preprints201610.0049.v1,.pp.1-13. 2016.

[25] Chan, E.W.C. and Wong, S.K. Phytochemical and pharmacology of three piper species: an update. Int. J.Pharmacognosy. 1(9), pp. 534544. 2014.

[26] T. Kawamoto, Use of new adhesive film for the preparation of multipurpose fresh-frozen sections from hard tissues, whole animals, insects, and plants. Arch.Histol.Cytol.66, pp. 123-143. 2003.

[27] Kawamoto, T. and Kawamoto, T. Preparation of thin frozen sections for mono-fixed and undecalcified hard tissues using Kawamoto's film method. I: Hilton, M.(ed) Skeletal Development and Repair. Methods in Mol.Biol.,vol 1130. Humana Press.Totowa, NJ, pp.149164. 2014.

[28] Wan-Yi. Chiou, K. Tsugane, T. Kawamoto, and M. Maekawa, Easy sectioning of a whole grain of rice using cryomicrotome, Breeding Sciences, 68, pp.381-385.2018.

[29] K.M. Omatola, and A.D. Onojah, Elemental analysis of rice husk ash using X-ray fluorescence technique. .International Journal of Physical Sciences, vol 4(4), pp. 189-193. 2003.

[30] B.L. Batista, L.R. Nacano, R.D. Freitas, C.C. de Oliveira-Souza and F. Barbosa. Determination of essential (Ca Fe, I,K,Mo) and toxic elements $(\mathrm{Hg}, \mathrm{Pb})$ in Brazilian rice grains and estimation of reference daily intake. Food and Nutrition Sciences, 3, pp. 129-134. 2012.

[31] R. Jayasekera, and M.C. Freitas, Concentration levels of major and trace elements in rice from Sri Lanka as determined by the k0 standardization method. Biological Trace Element Research, 103(1), pp. 83-96. 2005. 